University of Nebraska - Lincoln

DigitalCommons@University of Nebraska - Lincoln

Faculty Publications: Department of Entomology

Entomology, Department of

1973

\title{
Control of Leaf-Feeding Insects on Yellow-Poplar
}

E. A. Heinrichs

University of Tennessee, Knoxville, eheinrichs2@unl.edu

E. E. Burgess

University of Tennessee, Knoxville

Ellis L. Matheny Jr.

University of Tennessee, Knoxville

Follow this and additional works at: https://digitalcommons.unl.edu/entomologyfacpub

Part of the Entomology Commons

Heinrichs, E. A.; Burgess, E. E.; and Matheny, Ellis L. Jr., "Control of Leaf-Feeding Insects on Yellow-Poplar" (1973). Faculty Publications: Department of Entomology. 833.

https://digitalcommons.unl.edu/entomologyfacpub/833

This Article is brought to you for free and open access by the Entomology, Department of at DigitalCommons@University of Nebraska - Lincoln. It has been accepted for inclusion in Faculty Publications: Department of Entomology by an authorized administrator of DigitalCommons@University of Nebraska - Lincoln. 

permission.

Submitted January 11, 1973.

\title{
Control of Leaf-Feeding Insects on Yellow-Poplar
}

\author{
E. A. Heinrichs, E. E. Burgess, and Ellis L. Matheny, Jr.
}

Department of Agricultural Biology, University of Tennessee Agricultural Experiment Station, Knoxville, Tennessee, USA

E. A. Heinrichs, present address: American Consulate, DNPEA, Porto Alegre, Brazil, APO NY 09676; E. E. Burgess, present address: Agricultural Extension Service, 605 Airways Blvd., Jackson, TN 38301; E. L. Matheny, Jr., present address: Department of Biology, Motlow State Community College, Tullahoma, TN 37388.

Yellow-poplar, Liriodendron tulipifera L., also known as the tulip-poplar, is an important source of pulpwood and saw timber, and it is widely used as a shade tree. Numerous insect species attack the foliage of yellow-poplar. In 1965, Odontopus calceatus (Say) was first observed seriously damaging yellow-poplar in Tennessee (Russell and Stanley 1967). Defoliation was so severe at the University of Tennessee Oak Ridge Forest Experiment Station that growth reduction was attributed to this pest (Buckner 1972). In 1967, observations by one of us (E.A.H.) indicated that several other insects attack yellow-poplar leaves during the spring. Infestations of the aphid Macrosiphum liriodendri (Monell) and gall midges, Cecidomyia sp. and Thecodiplosis liriodendri Osten Sachen, were common. Cecidomyia sp. was called tulip vein gall, and T. liriodendri tulip spot gall, by Felt (1940), who described their damage. Since no measures had been determined for their control, a series of tests was conducted to determine the efficacy of various insecticide treatments.

\section{Methods and Materials}

Four tests were conducted from 1968 to 1971 at Oak Ridge Forest Experiment Station. Trees selected were 15-25 years old, ca. 30-40 ft tall, and .ca. 9-12 in. diam. In a preliminary test in 1968, dicrotophos technical was injected at $0.6,1.0$, and $1.6 \mathrm{ml} / \mathrm{in}$. DBH and oxydemetonmethyl at 1.6, 2.1, and $4.7 \mathrm{ml} / \mathrm{in}$. DBH. All injections were made with a Mauget injector unit (J. J. Mauget Co., 777 Front St., Burbank, CA 91502). Oxydemeton-methyl was applied 
as a bark spray at 2.0 and $5.0 \%$, and disulfoton $10 \mathrm{G}$ was applied under the drip line at 4.0 oz AI/in. DBH. Based on results of the preliminary test, only $\mathrm{G}$ systemics were used in the 1969-71 tests.

Prior to application of granules, leaf litter was removed from around the drip line. Granules were applied to the soil and raked in, just before leaf buds opened. Treatments were replicated 4 times, with 1 tree serving as a replicate. Observations on insect damage were made by removing 100 leaves from the upper and lower crown portion of each tree ca. 4 weeks posttreatment.

\section{Results}

All trees injected in the 1968 test exhibited phytotoxic effects varying from slight at the lower dosages to severe at higher. Oxydemeton-methyl at the $4.7 \mathrm{ml} / \mathrm{in}$. DBH rates caused total browning and drying of the leaves. Only disulfoton $\mathrm{G}$ provided promising results.

\section{M. liriodendri}

In the 1969 test, all treatments had significantly fewer aphid-infested leaves than the check (Table 1). Trees treated with disulfoton at the $8 \mathrm{oz} / \mathrm{in}$. DBH rate, hpad the lowest percent leaves infested (0.3 compared with 27.5 in check). In 1970, aphid populations were much lower, with only $4.5 \%$ of check leaves infested. All chemical treatments again reduced aphid infestation significantly below the check, with no leaves infested in the 8 oz/in. DBH disulfoton and in both carbofuran and phorate treatments.

Table 1. Effect of G. systemic insecticides on formation of galls by Cecidomyia sp. and T. liriodendri, and prevention of feeding by the aphid M. liriodendri, and weevil O. calceatus, 1969-71

\begin{tabular}{|c|c|c|c|c|c|c|c|c|c|}
\hline \multirow{2}{*}{$\begin{array}{l}\text { Insecticide } \\
\text { and formulation }\end{array}$} & \multirow{2}{*}{$\begin{array}{c}\text { Dosage } \\
\text { oz/in. DBH }\end{array}$} & \multicolumn{2}{|c|}{$\begin{array}{c}\text { \% leaves } \\
\text { with aphid, } \\
\text { M. liriodendri }\end{array}$} & \multirow{2}{*}{$\begin{array}{c}\text { \% leaves with } \\
\text { Cecidomyia sp. } \\
\text { vein galls } \\
1970\end{array}$} & \multicolumn{2}{|c|}{$\begin{array}{c}\text { \% leaves } \\
\text { with T. liriodendri } \\
\text { spot galls }\end{array}$} & \multicolumn{3}{|c|}{$\begin{array}{l}\text { \% leaves } \\
\text { with O. caleeatus } \\
\text { feeding damage }\end{array}$} \\
\hline & & 1969 & 1970 & & 1969 & 1970 & 1969 & 1970 & 1971 \\
\hline Disulfoton 10G & 4 & $3.3 \mathrm{~b}$ & $0.3 \mathrm{~b}$ & $15.8 \mathrm{c}$ & $67.3 \mathrm{ab}$ & $28.5 \mathrm{~b}$ & $41.3 \mathrm{a}$ & $59.7 \mathrm{ab}$ & $2.5 \mathrm{a}$ \\
\hline Disulfoton 10G & 8 & $0.3 \mathrm{~b}$ & $0.0 \mathrm{~b}$ & $2.8 \mathrm{c}$ & $67.0 \mathrm{ab}$ & $9.5 \mathrm{bc}$ & $31.5 \mathrm{a}$ & $69.3 \mathrm{ab}$ & $1.6 \mathrm{a}$ \\
\hline Phorate 10G & 4 & $8.0 \mathrm{~b}$ & $.0 \mathrm{~b}$ & $2.0 \mathrm{c}$ & $49.5 \mathrm{ab}$ & $9.3 \mathrm{bc}$ & $34.5 \mathrm{a}$ & $66.0 \mathrm{ab}$ & $1.6 \mathrm{a}$ \\
\hline Phorate 10G & 8 & $9.0 \mathrm{~b}$ & $.0 \mathrm{~b}$ & $1.8 \mathrm{c}$ & $54.0 \mathrm{ab}$ & $7.0 \mathrm{c}$ & $30.5 \mathrm{a}$ & $61.3 \mathrm{ab}$ & $2.0 \mathrm{a}$ \\
\hline Phorate-Thionazin & 4 & $-{ }^{b}$ & $.3 \mathrm{~b}$ & $32.3 \mathrm{~b}$ & - & $28.5 \mathrm{~b}$ & - & $72.0 \mathrm{ab}$ & - \\
\hline Phorate-Thionazin & 8 & - & $.3 \mathrm{~b}$ & $16.8 \mathrm{c}$ & - & $24.8 \mathrm{bc}$ & - & $63.0 \mathrm{ab}$ & - \\
\hline Carbofuran 10G & 4 & $2.0 \mathrm{~b}$ & $.0 \mathrm{~b}$ & $6.5 \mathrm{c}$ & $46.5 \mathrm{~b}$ & $20.8 \mathrm{bc}$ & $36.0 \mathrm{a}$ & $45.8 \mathrm{~b}$ & $1.0 \mathrm{a}$ \\
\hline Carbofuran 10G & 8 & $8.5 \mathrm{~b}$ & $.0 \mathrm{~b}$ & $11.8 \mathrm{c}$ & $70.5 \mathrm{ab}$ & $22.8 \mathrm{bc}$ & $33.5 \mathrm{a}$ & $54.3 \mathrm{ab}$ & $1.5 \mathrm{a}$ \\
\hline Check & & $27.5 \mathrm{a}$ & $4.5 \mathrm{a}$ & $52.5 \mathrm{a}$ & $75.3 \mathrm{a}$ & $50.0 \mathrm{a}$ & $49.8 \mathrm{a}$ & $81.3 \mathrm{a}$ & $1.6 \mathrm{a}$ \\
\hline
\end{tabular}

a. All means followed by the same letter are not significantly different at the 0.05 level of probability.

b. The Phorate-Thionazin treatment was not applied in 1969

\section{Cecidomyia sp.}

Vein galls were observed on $52.5 \%$ of check leaves. All chemical treatments significantly reduced gall attack below the check with trees treated with both phorate rates having lowest percent infestation. Phorate-Thionazin at $4 \mathrm{oz} / \mathrm{in}$. DBH provided poorest control, with $32.3 \%$ of leaves gall infested. 


\section{T. liriodendri}

Leaf-spot galls were abundant in both 1969 and 1970, with 75.3 and 50.0\% of check leaves infested, respectively. Only one of the treatments reduced gall infestation significantly below the check, but even then control was not satisfactory. In 1969, control was more effective, with all treatments having significantly fewer galls than the check. Phorate 10G at the 8 oz rate had lowest infestation $(7.0 \%$ compared with $50.0 \%$ in check).

\section{O. calceatus}

Percent attack was high in 1969 and 1970 and almost nil in 1971. None of the treatments provided satisfactory control, and only one reduced attack significantly below the check. Analyses of rainfall data indicate that each year ca. 2 in. fell within 2 weeks after G application. This amount was considered sufficient for dissolution and uptake of chemicals.

\section{References Cited}

Buckner, E. R. 1972. The influence of fertilization and irrigation treatments on trees in a natural yellowpoplar stand and on planted seedlings of selected species. PhD dissertation, Department of Forestry, North Carolina State University. 164 p.

Felt, E. P. 1940. Plant Galls and Gall Makers. Comstock Publishing Co., Inc., Ithaca, NY 364 p.

Russell, W. G., and W. W. Stanley. 1967. Observations of Odontopus calceatus (Coleoptera: Curculionidae), a leaf miner damaging yellow-popular. J. Tenn. Acad. Sci. 42: 93-96. 